modèles

ling uistiques

\section{Modèles linguistiques}

75 | 2017

Ecriture impressionniste et monologue intérieur (I)

\title{
Annexe : version originale des extraits traduits de George Moore (article 3)
}

George Moore

\section{(2) OpenEdition}

\section{Journals}

Édition électronique

URL : https://journals.openedition.org/ml/4465

DOI : $10.4000 / \mathrm{ml} .4465$

ISSN : 2274-0511

Éditeur

Association Modèles linguistiques

Édition imprimée

Date de publication : 29 décembre 2017

Pagination : 171-184

Référence électronique

George Moore, «Annexe : version originale des extraits traduits de George Moore (article 3) », Modèles linguistiques [En ligne], 75 | 2017, document 9, mis en ligne le 11 avril 2019, consulté le 01 juillet 2021. URL : http://journals.openedition.org/ml/4465; DOI : https://doi.org/10.4000/ml.4465

Ce document a été généré automatiquement le 1 juillet 2021

(c) Modèles Linguistiques 


\title{
Annexe : version originale des extraits traduits de George Moore (article 3)
}

\author{
George Moore
}

\section{Confessions of a Young Man (1888)}

([3] p. 35) At that moment the glass door of the café grated upon the sanded floor, and Manet entered. Although by birth and by art essentially Parisian, there was something in his appearance and manner of speaking that often suggested an Englishman. Perhaps it was his dress - his clean-cut clothes and figure. That figure! those square shoulders that swaggered as he went across a room and the thin waist; and that face, the beard and nose, satyr-like shall I say? No, for I would evoke an idea of beauty of line united to that of intellectual expression - frank words, frank passion in his convictions, loyal and simple phrases, clear as well-water, sometimes a little hard, sometimes, as they flowed away, bitter, but at the fountain head sweet and full of light. He sits next to Degas, that round-shouldered man in suit of pepper and salt. There is nothing very trenchantly French about him either, except the large necktie; his eyes are small and his words are sharp, ironical, cynical. These two men are the leaders of the impressionist school. Their friendship has been jarred by inevitable rivalry. "Degas was painting 'Semiramis' when I was painting 'Modern Paris," says Manet. Manet is in despair because he cannot paint atrocious pictures like Durant, and be fêted and decorated; he is an artist, not by inclination, but by force. "He is as a galley slave chained to the oar," says Degas. Different too are their methods of work. Manet paints his whole picture from nature, trusting his instinct to lead him aright through the devious labyrinth of selection. Nor does his instinct ever fail him, there is a vision in his eyes which he calls nature, and which he paints unconsciously as he digests his food, thinking and declaring vehemently that the artist should not seek a synthesis, but should paint merely what he 
sees. This extraordinary oneness of nature and artistic vision does not exist in Degas, and even his portraits are composed from drawings and notes (Chapitre VI : 89-90).

2 ([4] p. 36) Not the thing itself, but the idea of the thing evokes the idea. Schopenhauer was right; we do not want the thing, but the idea of the thing. The thing itself is worthless; and the moral writers who embellish it with pious ornamentation are just as reprehensible as Zola, who embellishes it with erotic arabesques. You want the idea drawn out of obscuring matter, and this can best be done by the symbol. The symbol, or the thing itself, that is the great artistic question. In earlier ages it was the symbol; a name, a plume, sufficed to evoke the idea; now we evoke nothing, for we give everything, the imagination of the spectator is no longer called into play (chapitre XI : 47)

3 ([5] p. 37) I see the Rougon-Macquart series, each volume presented to him [Paul Alexis] by the author, Goncourt, Huysmans, Duranty, Céard, Maupassant, Hennique, etc.; in a word, the works of those with whom I grew up, those who tied my first literary pinafore round my neck. But here are "Les Moralités Legendaires" by Jules Laforgue, and "Les Illuminations" by Rimbaud. Paul has not read these books; they were sent to him, I suppose, for review, and put away on the bookcase, all uncut; their authors do not visit here. And this sets me thinking that one knows very little of any generation except one's own. True that I know a little more of the symbolists than Paul. I am the youngest of the naturalists, the eldest of the symbolists. The naturalists affected the art of painting, the symbolists the art of music; and since the symbolists there has been no artistic manifestation - the game is played out. When Huysmans and Paul and myself are dead, it will be as impossible to write a naturalistic novel as to revive the megatherium. Where is Hennique? When Monet is dead it will be as impossible to paint an impressionistic picture as to revive the ichthyosaurus. A little world of ideas goes by every five-and-twenty years, and the next that emerges will be incomprehensible to me, as incomprehensible as Monet was to Corot....

4 ([7] p. 39) O, my father, I, who love and reverence nothing else, love and reverence thee; thou art the one pure image in my mind, the one true affection that life has not broken or soiled; I remember thy voice and thy kind, happy ways. All I have of worldly goods and native wit I received from thee - and was it I who was glad ? No, it was not I ; I had no concern in the thought that then fell upon me unbidden and undesired; my individual voice can give you but praise and loving words ; and the voice that said 'I am glad' was not my voice, but that of the will to live which we inherit from elemental dust through countless generations. Terrible and imperative is the voice of the will to live: let him who is innocent cast the first stone. Terrible is the day when each sees his soul naked, stripped of all veil; that dear soul which he cannot change or discard, and which is so irreparably his. My father's death freed me, and I sprang like a loosened bough up to the light. His death gave me power to create myself, that is to say, to create a complete and absolute self out of the partial self which was all that the restraint of home had permitted; this future self, this ideal George Moore, beckoned me, lured like a ghost; and as I followed the funeral the question, Would I sacrifice this ghostly self, if by so doing I should bring my father back? presented itself without intermission, and I shrank horrified at the answer which I could not crush out of mind (édition $1904: 10$, amputé de l'édition américaine).

5 ([12] p. 44) What I reproach Zola with is that he has no style; there is nothing you won't find in Zola from Chateaubriand to the reporting in the Figaro. He seeks immortality in 
an exact description of a linendraper's shop; if the shop conferred immortality it should be upon the linendraper who created the shop, and not on the novelist who described it. And his last novel "l'ÆEuvre," how spun out, and for a franc a line in the "Gil Blas." Not a single new or even exact observation. And that terrible phrase repeated over and over again - "La Conquête de Paris." What does it mean? I never knew anyone who thought of conquering Paris; no one ever spoke of conquering Paris except, perhaps, two or three provincials (Chapitre VII, "The Synthesis of the Nouvelle Athènes": 97).

\section{Impressions and Opinions (1894)}

([13] p. 45) As before, Zola was lying on the sola by the window and after a few words of greeting, he said : " l'm afraid, my dear friend, that I shall not be able to write the preface. You have made it impossible for me to do so." The phrases I had used when subjected to a close critical examination proved more difficult of explanation than I had anticipated. The discussion was painful, and the breakfast bell was a welcome relief. "It's over at last," I said to myself; but to my horror instead of answering my thought the master said:

"We are going down to breakfast now, but after breakfast we will go into the matter thoroughly; I will read the passages aloud to you." "Good Heavens!" I thought, "I wish I hadn't come." After breakfast Zola, Alexis, and myself walked in the garden talking of indifferent things for an hour or more. Then Zola said: "We will now go upstairs." He led the way, and 1 followed, feeling very much as 1 used to feel at school when ordered a flogging. The master lay on the sofa; I took a small chair; he said: "you'll be more comfort-able in a larger one." The passages were already marked, and they were read to me in a low and deliberate voice. I listened, thinking what was the best defence to set up; Zola commented on every fresh sarcasm. " How can 1 write your preface after that! I want to, you know, but 1 ask you how can I? Listen! " "Don't you see, my dear friend, that that book is not my real opinion about life and things, but rather an attempt to reduce to words the fugitive imaginings of my mind, its intimate workings, its shifting colours? Has it never come to you to think differently about things? To find your mind is a ferment of contradiction?" "No," he said, "1 do not change my opinions easily. There is Alexis" (he was indeed there, round as a barrel with the in-evitable cigar between his teeth); "1 have known Alexis these five and twenty years, and I think of him to-day exactly as I always thought of him. With me an opinion is like a heavy piece of furniture; it is moved with difficulty." "But," 1 said, "the passages you have just read are from a chapter entitled 'La Synthèse de la Nouvelle Athenes' ... and must be taken as an expression of the opinions of the various ratés who assemble there."

"1 will admit that as a legitimate defence, but you see the opinions expressed in the café coincide exactly with those which you express yourself in an earlier part of the book."

I had to fall back on the original defence, that a contradictory thinking should not be taken for the opinions which he holds by and abides by. " How often do we hear Christians make jokes against Christianity?" 1 thought the argument specious, but Zola did not notice it. He continued reading: "After what you have written about Goncourt," he said, "you never can go to his house again." " I don't want to ; he isn't a friend." "The disciples, the childish vanity, the bric-à-brac, even the accusation of making copy out of his brother's corpse, tout est là, rien ne manque. What you say of me is nothing 
compared with what you say of Goncourt." I hastened to concur in this opinion, but Zola was not to be wheedled. "No, my dear friend," he said gravely and sadly, "you don't call your book Mémoires d'un Jeune Anglais you say Confessions d'un Jeune Anglais, and when we use the word Confessions we mean that at last we are going to tell the truth. 1 have gone through these pages calling attention to the expressions used, not because I am angry, but because I want to convince you that you have made it impossible for me to write the preface to your Mummer's Wife. What you think of me does not affect me, no, I won't say that; we are old friends. What you say about me does affect me, I mean that nothing that you can say can affect my position .... You admit in your book that you owe your first inspiration to me. I am proud that this is so, and thank you for saying it. I am sorry you have changed your opinions; after all it is the eternal law - children devour their fathers. I make no complaint. Nature has willed it so."

He spoke these words sadly as he walked across the room. The twilight was gathering, the great furniture loomed up like shadows. There were tears in my eyes. Never did I feel so distinct a sensation of my inferiority; the man was great in his simplicity. "The man is greater than his books", I said to myself, "and that is a great deal, for he has written many fine books" (71-73).

\section{Reminiscences of the Impressionist Painters (1906)}

7 ([11] p. 44) I should emphasize Manet's courage, for without courage there cannot be art. We have all heard the phrase, "I should not like to think like that," and whosoever feels that he would not like to think out to its end every thought that may happen to come into his mind I would dissuade from art if I could. Maner's art is the most courageous ever seen. One looks in vain for those subterfuges that we find in every other painter. What he saw he stated candidly, almost innocently, and what he did not see he passed over, Never in his life did he stop to worry over a piece of drawing that did not interest him because it was possibly that somebody might notice the omission. It was part of his genius to omit what did not interest him (14-15).

\section{Memoirs of my Dead Life (1906)}

8 ([16] p. 47) As I sit at my window on Sunday morning, lazily watching the sparrows restless black dots that haunt the old tree at the corner of King's Bench Walk - I begin to distinguish a faint green haze in the branches of the old lime. Yes, there it is green in the branches; and I'm moved by an impulse - the impulse of Spring is in my feet; indiarubber seems to have come into the soles of my feet, and I would see London. It is delightful to walk across Temple Gardens, to stop - pigeons are sweeping down from the roofs--to call a hansom, and to notice, as one passes, the sapling behind St. Clement's Danes. The quality of the green is exquisite on the smoke-black wall. London can be seen better on Sundays than on week-days; lying back in a hansom, one is alone with London. London is beautiful in that narrow street, celebrated for licentious literature. The blue and white sky shows above a seventeenth-century gable, and a few moments after we are in Drury Lane. The fine weather has enticed the population out of grim courts and alleys; skipping-ropes are whirling everywhere. The children hardly escape being run over. Coster girls sit wrapped in shawls, contentedly, like rabbits at 
the edge of a burrow; the men smoke their pipes in sullen groups, their eyes on the closed doors of the public house (1-2).

9 ([25] p. 55) It was early in the evening when I returned home, and, sitting in the window, I read till surprised by the dusk; and when my eyes could no longer follow the printed page, holding the book between finger and thumb, my face resting on the other hand, I looked out on the garden, allowing my heart to fill with dreams. The book that had interested me dealt with the complex technique of the art of the Low Countries--a book written by a painter. It has awakened in me memories of all kinds, heart rending struggles, youthful passion, bitter disappointments; it has called into mind a multitude of thoughts and things, and, wearied with admiring many pictures and arguing with myself, I am now glad to exchange my book for the gentle hallucinations of the twilight.

10 I see a line of leafage drawn across the Thames, but the line dips, revealing a slip of grey water with no gleam upon it. Warehouses and a factory chimney rise ghostly and grey, and so cold is that grey tint that it might be obtained with black and white; hardly is the warmth of umber needed. Behind the warehouses and the factory chimney the sky is murky and motionless, but higher up it is creamy white, and there is some cloud movement. Four lamps, two on either side of the factory chimney, look across the river; one constantly goes out - always the same lamp - and a moment after it springs into its place again. Across my window a beautiful branch waves like a feather fan. It is the only part of the picture worked out in detail. I watch its soft and almost imperceptible swaying, and am tempted to count the leaves. Below it, and a little beyond it, between it and the river, night gathers in the gardens; and there, amid serious greens, passes the black stain of a man's coat, and, in a line with the coat, in the beautifully swaying branch, a belated sparrow is hopping from twig to twig, awakening his mates in search for a satisfactory resting-place. In the sharp towers of Temple Gardens the pigeons have gone to sleep. I can see the cots under the conical caps of slate.

11 The gross, jaded, uncouth present has slipped from me as a garment might, and I see the past like a little show, struggles and heartbreakings of long ago, and watch it with the same indifferent curiosity as I would the regulated mimicry of a stage play. Pictures from the past come and go without an effort of will; many are habitual memories, but the one before me rises for the first time - for fifteen years it has lain submerged, and now like a water weed or flower it rises - the Countess Ninon de Calvador's boudoir! Her boudoir or her drawing-room, be that as it may, the room into which I was ushered many years ago when I went to see her. I was then a young man, very thin, with sloping shoulders, and that pale gold hair that Manet used to like to paint. I had come with a great bouquet for Ninon, for it was son jour de fête, and was surprised and somewhat disappointed to meet a large brunette with many creases in her neck, a loose and unstayed bosom; one could hardly imagine Ninon dressed otherwise than in a peignoira blue peignoir seemed inevitable (Chapitre VII : 75-76).

\section{Ave, Salve, Vale (1911-1914)}

[21] "Ave", p. 110) One does not like to speak of a double self, having so often heard young women say they fear they never can be really in love, because of a second self which spies upon the first, forcing them to see the comic side even when a lover pleads. Yet if I am to give a full account of my visit to Dublin, it seems necessary that I should 
speak of my self-consciousness, a quality which I share with every human being; but as no two human beings are alike in anything, perhaps my self-consciousness may be different from another's. The reader will be able to judge if this be so when he reads how mine has been a good friend to me all my life, helping me to while away the tediousness of walks taken for health's sake, covering my face with smiles as I go along the streets; many have wondered, and never before have I told the secret of my smiling face. In my walks comedy after comedy rises up in my mind, or I should say scene after scene, for there are empty interspaces between the scenes, in which I play parts that would have suited Charles Mathews excellently well. The dialogue flows along, sparkling like a May morning, quite different from any dialogue that I should be likely to find pen in hand, for in my novels I can write only tragedy, and in life play nothing but light comedy, and the one explanation that occurs to me of this dual personality is that I write according to my soul, and act according to my appearance.

The reader will kindly look into his mind, and when the point has been considered he will be in a mood to take up my book again and to read my story with profit to himself. These unwritten dialogues are often so brilliant that I stop in my walk to repeat a phrase, making as much of it as Mathews or Wyndham would make, regretting the while that none of my friends is by to hear me. All my friends are actors in these unwritten plays, and almost any event is sufficient for a theme on which I can improvise. But never did Nature furnish me with so rich a theme as she did when Yeats and Edward came to see me in Victoria Street. The subject was apparent to me from the beginning, and the reason given for my having agreed to act with them in the matter of the Irish Literary Theatre (the temptation to have a finger in every literary pie) has to be supplemented. There was another, and a greater temptation - the desire to secure a good part in the comedy which I foresaw, and which had for the last three weeks unrolled itself, scene after scene, exceeding any imagination of mine (113-115).

([27] "Vale“, p. 590-598) Unfortunately rubbing salt into the wound, I said. A story that will amuse Dujardin and it will be great fun telling him in the shady garden at Fontainebleau how Edward, anxious to do something for his church, had succeeded in emptying two. All the way down the alleys he will wonder how Edward could have ever looked upon Palestrina's masses as religious music. The only music he will say, in which religious emotion transpires is plain-chant. Huysmans says that the Tantum Ergo or the Dies Irae, one or the other, reminds him of a soul being dragged out of purgatory, and it is possible that it does; but a plain-chant tune arranged in eight-part counterpoint cannot remind one of anything very terrible. Dujardin knows that Palestrina was a priest, and he will say: That fact deceived your friend, just as the fact of finding the Adeste Fideles among the plain-chant tunes deceived him. For of course I shall tell Dujardin that story too. It is too good to be missed. He is wonderful, Dujardin! I shall cry out in one of the sinuous alleys. There never was anybody like him! And I will tell him more soul-revealing anecdotes. I will say: Dujardin, listen. One evening he contended that the great duet at the end of Siegfried reminded him of mass by Palestrina. Dujardin will laugh, and, excited by his laughter, I will try to explain to him that what Edward sees is that Palestrina took a plain-chant tune and gave fragments of it to the different voices, and in his mind these become confused with the motives of The Ring. You see, Dujardin, the essential always escapes him - the intention of the writer is hidden from him. I am beginning to understand your friend. He has, let us suppose, a musical ear that allows him to take pleasure in the music; but a musical ear 
will not help him to follow Wagner's idea - how, in a transport of sexual emotion, a young man and a young woman on a mountain-side awaken to the beauty of the life of the world. Dujardin's appreciations will provoke me, and I will say: Dujardin, you shouldn't be so appreciative. If I were telling you of a play I had written, it would be delightful to watch my idea dawning upon your consciousness; but I am telling you of a real man, and one that I shall never to able to get into literature. He will answer: We invent nothing; we can but perceive. And then, exhilarated, carried beyond myself, I will say: Dujardin, I will tell you something still more wonderful than the last gaffe. II gaffe dans les Quat'z Arts. He admires Ibsen, but you'd never guess the reason why because he is very like Racine; both of them, he says, are classical writers. And do you know how he arrived at that point? Because nobody is killed on the stage in Racine or in Ibsen. He does not see that the intention of Racine is to represent men and women out of time and out of space, unconditioned by environment, and that the very first principle of Ibsen's art is the relation of his characters to their environment. In many passages he merely dramatises Darwin. There never was anybody so interesting as dear Edward, and there never will be anybody like him in literature ... I will explain why presently, but I must first tell you another anecdote. I went to see him one night, and he told me that the theme of the play he was writing was a man who had married a woman because he had lost faith in himself; the man did not know, however, that the woman had married him for the same reason, and the two of them were thinking - I have forgotten what they were thinking, but I remember Edward saying: I should like to suggest hopelessness. I urged many phrases, but he said: It isn't a phrase I want, but an actual thing. I was thinking of a broken anchor - that surely is a symbol of hopelessness. Yes, I said, no doubt, but how are you going to get a broken anchor into a drawing-room? I don't write about drawing-rooms. Well, living-rooms. It isn't likely that they would buy a broken anchor and put it up by the coal-scuttle.

There's that against it, he answered. If you could suggest anything better - What do you think of a library in which there is nothing but unacted plays? The characters could say, when there was nothing for them to do on the stage, that they were going to the library to read, and the library would have the advantage of reminding everybody of the garret in The Wild Duck. A very cruel answer, my friend, Dujardin will say, and I will tell him that I can't help seeing in Edward something beyond Shakespeare or Balzac. Now, tell me, which of these anecdotes I have told you is the most humorous? He will not answer my question, but a certain thoughtfulness will begin to settle in his face, and he will say: Everything with him is accidental, and when his memory fails him he falls into another mistake, and he amuses you because it is impossible for you to anticipate his next mistake. You know there is going to be one; there must be one, for he sees things separately rather than relatively. I am beginning to understand your friend.

You are, you are; you are doing splendidly. But you haven't told me, Dujardin, which anecdote you prefer. Stay, there is another one. Perhaps this one will help you to a still better understanding. When he brought The Heather Field and Yeats's play The Countess Cathleen to Dublin for performance, a great trouble of conscience awakened suddenly in him, and a few days before the performance he went to a theologian to ask him if The Countess Cathleen were a heretical work, and, if it were would Almighty God hold him responsible for the performance? But he couldn't withdraw Yeats's play without withdrawing his own, and it appears that he breathed a sigh of relief when a common friend referred the whole matter to two other theologians, and as these gave their 
consent Edward allowed the plays to go on; but Cardinal Logue intervened, and wrote a letter to the papers to say that the play seemed to him unfit for Catholic plays if the Cardinal hadn't admitted in his letter that he had judged the play by certain extracts only.

He wishes to act rightly, but has little faith in himself; and what makes him so amusing is that he needs advice in aesthetics as well as in morals. We are, I said, Dujardin, at the roots of conscience. And I began to ponder the question what would happen to Edward if we lived in a world in which aesthetics ruled: I should be where Bishop Healy is, and he would be a thin, small voice crying in the wilderness - an amusing subject of meditation, from which I awoke suddenly.

I wonder how Dujardin is getting on with his Biblical studies? Last year he was calling into question the authorship of the Romans - a most eccentric view; and, remembering how weakly I had answered him, I took the Bible from the table and began to read the Epistle with a view to furnishing myself with arguments wherewith to confute him. My Bible opened at the ninth chapter, and I said: Why, here is the authority for the Countess Cathleen's sacrifice which Edward's theologian deemed untheological. It will be great fun to poke Edward up with St Paul, and on my way to Lincoln Place I thought how I might lead the conversation to The Countess Cathleen.

Image 2000000C0000422C000017519FA3269A.wmf

20 A few minutes afterwards a light appeared on the staircase and the door slowly opened. Come in, Siegfried, though you were off the key.

21 Well, my dear friend, it is a difficult matter to whistle above two trams passing simultaneously and six people jabbering round a public-house, to say nothing of a jarvey or two, and you perhaps dozing in your armchair, as your habit often is. You won't open to anything else except a motive from The Ring; and I stumbled up the stairs in front of Edward, who followed with a candle. Wait a moment; let me go first and I'll turn up the gas. You aren't sitting in the dark, are you?

No, but I read better by candle-light, and he blew out the candles in the tin candelabrum that he had made for himself. He is original even in his candelabrum; no one before him had ever thought of a caridelabrum in tin, and I fell to admiring his appearance more carefully than perhaps I had ever done before, so monumental did he seem lying on the little sofa sheltered from daughts by a screen, a shawl about his shoulders. His churchwarden was drawing famously, and I noticed his great square hands with strong fingers and square nails pared closely away, and as heretofore I admired the curve of the great belly, the thickness of the thighs, the length and breadth and the width of his foot hanging over the edge of the sofa, the apoplectic neck falling into great rolls of flesh, the humid eyes, the skull covered with short stubbly hair. I looked round the rooms and they seemed part of himself: the old green wallpaper on which he pins reproductions of the Italian masters. And I longed to peep once more into the bare bedroom into which he goes to fetch bottles of Apollinaris. Always original! Is there another man in this world whose income is two thousand a year, and who sleeps in a bare bedroom, without dressing-room, or bathroom, or servant in the house to brush his clothes, and who has to go to the baker's for his breakfast?

We had been talking for some time of the Gaelic League, and from Hyde it was easy to pass to Yeats and his plays. His best play is The Countess Cathleen. 
The Countess Cathleen is only a sketch. But what I never could understand, Edward, was why you and the Cardinal could have had any doubts as to the orthodoxy of The Countess Cathleen. What, a woman that sells her own soul in order to save the souls of others! I suppose your theologian objected - of course he objected. He cannot have read St Paul. What do you mean? He can't have read St Paul, or else he is prepared to throw over St Paul. Mon ami Moore, mon ami Moore. The supernatural idealism of a man who would sell his soul to save the souls of others fills me with awe. But it wasn't a man; it was the Countess Cathleen, and women are never idealists. Not the saints?

His face grew solemn at once.

If you give me the Epistles I will read the passage to you. And it was great fun to go to the bookshelves and read: I say the truth in Christ, I lie not, my conscience also bearing me witness in the Holy Ghost, that I have great heaviness and continual sorrow in my heart. For I could wish that myself were accursed from Christ for my brethren, my kinsmen according to the flesh.

Edward's face grew more and more solemn, and I wondered of what he was thinking. Paul is a very difficult and a very obscure writer, and I think the Church is quite right not to encourage the reading of the Epistles, especially without comments. Then you do think there is something in the passage I have read?

After looking down his dignified nose for a long time, he said: Of course, the church has an explanation. All the same, it's very odd that St Paul should have said such a thing very odd.

There is no doubt that I owe a great deal of my happiness to Edward; all my life long he has been exquisite entertainment. And I fell to thinking that Nature was very cruel to have led me, like Moses, within sight of the Promised Land. A story would be necessary to bring Edward into literature, and it would be impossible to devise an action of which he should be a part. The sex of a woman is odious to him, and a man with two thousand a year does not rob nor steal, and he is so uninterested in his fellow-men that he has never an ill word to say about anybody. John Eglinton is a little thing; AE is a soul that few will understand; but Edward is universal - more universal than Yeats, than myself, than any of us, but for lack of a story I shall not be able to give him the immortality in literature which he seeks in sacraments. Shakespeare always took his stories from some other people. Turgenev's portrait of him would be thin, poor, and evasive, and Balzac would give us the portrait of a mere fool. And Edward is not a fool. As I understand him he is a temperament without a rudder; all he has to rely upon is his memory, which isn't a very good one, and so he tumbles from one mistake into another. My God! it is a terrible thing to happen to one, to understand a man better than he understands himself, and to be powerless to help him. If I had been able to undo his faith I should have raised him to the level of Sir Horace Plunkett, but he resisted me; and perhaps he did well, for he came into the world seeing things separately rather than relatively, and had to be a Catholic. He is a born Catholic, and I remembered one of his confessions - a partial confession, but a confession: If you had been brought up as strictly as I have been - I don't think he ever finished the sentence; he often leaves sentences unfinished, as if he fears to think things out. The end of the sentence should run: You would not dare to think independently. He thinks that his severe bringing-up has robbed him of something. But the prisoner ends by liking his prison-house, and on another occasion he said: If it hadn't been for the Church, I don't know what would have happened to me. 
My thoughts stopped, and when I awoke I was thinking of Hughes.

Perhaps the link between Hughes and Edward was Loughrea Cathedral. He had shown me a photograph of some saints modelled by Hughes. Hughes is away in Paris, I said, modelling saints for Loughrea Cathedral. The last time I saw him was at Walter Osborne's funeral, and Walter's death set me thinking of the woman I had lost, and little by little all she had told me about herself floated up in my mind like something that I had read. I had never seen her father nor the Putney villa in which she had been brought up, but she had made me familiar with both through her pleasant mode of conversation, which was never to describe anything, but just to talk about things, dropping phrases here and there, and the phrases she dropped were so well chosen that the comfort of the villa, its pompous meals and numerous servants, its gardens and greenhouses, with stables and coach-house just behind, are as well known to me as the house that I am living in, better known in a way, for I see it through the eyes of the imagination ... clearer eyes than the physical eyes.

It does not seem to me that any one was ever more conscious of whence she had come and of what she had been; she seemed to be able to see herself as a child again, and to describe her childhood with her brother (they were nearly the same age) in the villa and in the villa's garden. I seemed to see them always as two rather staid children who were being constantly dressed by diligent nurses and taken out for long drives in the family carriage. They did not like these drives and used to hide in the garden; but their governess was sent to fetch them, and they were brought back. Her father did not like to have the horses kept waiting, and one day as Stella stood with him in the passage, she saw her mother come out of her bedroom beautifully dressed. Her father whispered something in his wife's ear, and he followed her into her bedroom. Stella remembered how the door closed behind them. In my telling, the incident seems to lose some of its point, but in Stella's relation it seemed to put her father and his wife before me and so clearly that I could not help asking her what answer her father would make were she to tell him that she had a lover. A smile hovered in her grave face. He would look embarrassed, she said, and wonder why I should have told him such a thing, and then I think he would go to the greenhouse, and when he returned he would talk to me about something quite different. I don't think that Stella ever told me about the people that came to their house, but people must have come to it, and as an example of how a few words can convey an environment I will quote her: I always wanted to talk about Rossetti, she said, and these seven words seem to me to tell better than any description the life of a girl living with a formal father in a Putney villa, longing for something, not knowing exactly what, and anxious to get away from home.... I think she told me she was eighteen or nineteen and had started painting before she met Florence at the house of one of her father's friends; a somewhat sore point this meeting was, for Florence was looked upon by Stella's father as something of a Bohemian. She was a painter, and knew all the Art classes and the fees that had to be paid, and led Stella into the world of studios and models and girl friends. She knew how to find studios and could plan out a journey abroad. Stella's imagination was captured, and even if her father had tried to offer opposition to her leaving home he could not have prevented her, for she was an heiress (her mother was dead and had left her a considerable income); but he did not try, and the two girls set up house together in Chelsea; they travelled in Italy and Spain; they had a cottage in the country; they painted pictures and exhibited their pictures in the same exhibitions; they gave dances in their studios and were attracted by this young man and the other; but Stella did not give herself to 
any one, because, as she admitted to me, she was afraid that a lover would interrupt the devotion which she intended to give to Art. But life is forever casting itself into new shapes and forms, and no sooner had she begun to express herself in Art than she met me. I was about to go to Ireland to preach a new gospel, and must have seemed a very impulsive and fantastic person to her, but were not impulsiveness and fantasy just the qualities that would appeal to her? And were not gravity and good sense the qualities that would appeal to me, determined as I was then to indulge myself in a little madness? 